\title{
Influence of different packaging on the storage of milk candy in tablets
}

\author{
Diogo Cunha FURTADO ${ }^{1}$, Lismaíra Gonçalves Caixeta GARCIA ${ }^{1}$ (D), Daiane Sousa PERES ${ }^{1}$, \\ Flávio Alves da SILVA², Priscila Alonso dos SANTOS ${ }^{1^{*}}$
}

\begin{abstract}
The objective of this study was to evaluate the influence of different packaging on the storage of milk candy in tablets by means of moisture, ash, lipid, protein, colour and texture profile analysis. The were used: Expanded polystyrene wrapped with polyvinyl chloride film (PVC), polypropylene (PP) and low-density polyethylene (PEBD) bags. The experiment was conducted in a completely randomised design, and the evaluations were carried out at 0, 45, 90, 135 and 180 days. All treatments presented darkening of the milk candy; however, those candies packaged in PVC presented a light and yellow colour $\left(\mathrm{L}=39.84, \mathrm{~b}^{*}=20.06\right)$, while those in PEBD presented a dark colour $(\mathrm{L}=36.75)$. According to the conditions studied, PVC packaging is not recommended for the storage of milk candy in tablets due to the intense changes in the physical-chemical characteristics, texture and colour. In contrast, PVC, PP and PEBD packages are efficient materials for maintaining the initial properties of this type of candy.
\end{abstract}

Keywords: dairy concentrate; storage; packaging; tablets.

Practical Application: Determination of the best packaging for the storage of milk candy in tablets.

\section{Introduction}

Milk is a typical product of South America, mainly in Argentina, Brazil (Silva et al., 2015) and Uruguay, and is also present in Chile, Paraguay and Bolivia (Zalazar \& Perotti, 2011). Typically, milk is consumed pure or combined with breads, biscuits, cheeses, and fruits (Souza et al., 1990). Milk candy is a product obtained by the concentration of milk added with sucrose, which acquires its own color, texture and flavor as a result of non-enzymatic browning reactions, being highly appreciated by consumers (Cardoso et al., 2018). Other food substances, milk and/or cream solids, additives and technology adjuvants can be added. Sucrose is a mandatory ingredient; up to $30 \mathrm{~kg}$ can be added for every 100 litres of milk, and up to $40 \%(\mathrm{~m} / \mathrm{m})$ can be substituted for mono- and disaccharides (Brasil, 1997).

It is perceived a great importance of dairy products, especially milk candy, for the national market (Jacob et al., 2018). Although milk candy is a product of great consumption and of great economic importance, little research has been done on it (Pavlovic et al., 1992), with few scientific references regarding sweet milk in tablets. In Brazil, the production of milk candy is very varied, which can vary from artisanal manufacture to large scale industrial production; and it is a product found throughout the country. This diversity often implies a lack of uniformity and standardization (Jacob et al., 2018), generating great variability in the physical-chemical and sensorial characteristics of the sweets, constituting a barrier to the European and North American market (Perrone, 2007; Gaze et al., 2015).

In addition to process control, the barrier properties of packaging can prevent product defects, especially at high temperatures and overly ventilated locations (Martins \& Lopes, 1980). Two of the important barrier properties of the packaging material include water barrier and oxygen barrier. The water barrier and oxygen barrier properties of the packaging material are important aspects for the application of food packaging in which the properties will affect the useful life of the product packed with the material (Othman et al., 2019). During storage, the oxygen level in the product packaging must be as low as possible (Akarca, 2019).

The characteristics of a package depend on the type of food you want to protect and the desired features (Fernandes et al., 2020). Pasty milk can be packaged in glass, plastic, plastic bags and others (Pinto, 1979). While candy in tablets is recommended to be packed in plastic forms previously lined with plastic, polyvinyl chloride (PVC) or other waterproof plastic (Vieira \& Lourenço, 2004), the changes in the physical-chemical, microbiological and texture parameters of the candy in bar or tablets during storage are not known from a scientific point of view.

Monitoring the microbiological stability of milk candy is important because despite its low perishability resulting from the long period of cooking at high temperature, which causes the conditions to be not favourable for microbiological growth and the addition of sugar and osmotic pressure, the growth of microorganisms cannot be ruled out. The possibility of microbial growth is a concern of the government agencies of food inspection and public health (Timm et al., 2007; Hentges et al., 2010). 
In view of the above, the objective of this study was to determine the physico-chemical, microbiological, colour and texture characteristics of sweet milk samples in tablets stored in three different materials (Styrofoam trays with PVC, polypropylene (PP) and low-density polyethylene (PEBD)) were analysed during $0,45,90,135$ and 180 days of storage.

\section{Materials and methods}

\subsection{Preparation of milk candy in tablets}

The milk candy was manufactured in the facilities of an Agribusiness located in Rio Verde - GO. The sweets were processed in an open-tuxedo, double-mantle Mundinox ${ }^{\circledR}$ system with a total capacity of 200 litres of milk, made of stainless steel (304 AISI) and equipped with a stirring blade with a maximum working pressure of $2.5 \mathrm{kgf} / \mathrm{cm}^{3}$. First, the equipment, utensils (stainless steel table, bucket, knife, etc.) and structural parts (floor, walls, sink, etc.) were cleaned and sanitised in accordance with good manufacturing practice standards (Brasil, 2002).

Initially, the solid ingredients and technology coatings were weighed, and 120 litres of whole raw milk from the factory cooling tank were pumped into the jacketed tacho using a centrifugal pump. Thirty kilograms of sucrose (crystal sugar, Cristal Alimentos $\left.{ }^{\otimes}\right)$ at a ratio of $25 \%(\mathrm{w} / \mathrm{v})$ of the volume of milk, $0.067 \mathrm{~kg}$ of sodium bicarbonate (Kitano ${ }^{\oplus}$, Yoki Alimentos Ltda.), and $0.050 \mathrm{~kg}$ of potassium sorbate PA (Dynamics Química Contemporânea Ltda) were used.

The titratable acidity of whole raw milk $\left(16^{\circ} \mathrm{D}\right)$ was analysed by titration with sodium hydroxide $(\mathrm{NaOH} 0.1 \mathrm{~N}$ - Fort Química $^{\circledR}$ ), according to Brasil (2006). Then, the titratable acidity of the milk was reduced to $13^{\circ} \mathrm{D}$ to avoid the precipitation of proteins during the heat treatment through the auxiliary sodium bicarbonate with $100 \%$ purity. Equation 1 was used to calculate the quantity of sodium bicarbonate to be added, according to Perrone et al. (2011).

$\mathrm{R}=\frac{0.1 \times \mathrm{D} \times \mathrm{V} \times 0.9333}{\mathrm{~PB}}$

where: $R$ is the amount of sodium bicarbonate to be added (grams); $D$ corresponds to the acidity to be reduced (Dornic degrees); $V$ is the volume of milk (litres); and $P B$ is the purity of sodium bicarbonate.

With mechanical stirring, the acid-reducing agent was added to a pan, and the steam inlet valve (VSV) was held open until the line condensate was discharged to start heating. Sugar was added according to the procedure adopted by the Agroindustry, and the amount of sucrose and milk (120 L) of the formulation was added to the pan to form a syrup. Thereafter, after the first boil, the whole volume of the syrup was divided, and small portions were added over the course of the cooking process with the working pressure at 30 psi. This method can also be used to reduce the time of manufacturing when the volume per batch is high. After 4 hours of constant heating and stirring, soluble solids (SS) were analysed using a digital refractometer to determine the point of milk jam previously stipulated at $75^{\circ}$ Brix. The remaining steps were carried out according to Agroindustry's own methodology. After reaching the desired SS content, the steam supply to the pan was cooled to zero, and the preservative potassium sorbate PA $(0.050 \mathrm{~kg})$ was added immediately. At that time, an annealing or controlled crystallisation step was established with constant stirring for 1.25 hours until a mass of sweets with a dried or dull surface of approximately $40^{\circ} \mathrm{C}$ was obtained. Afterwards, the sweets were placed on a flat, properly sanitised stainless steel table and rested for 12 hours to solidify.

The mass of milk candy was deemed ready for cutting when the blade of a knife came out clean and without sweets adhered. After cutting the solid mass into tablets $(2 \times 2 \times 8 \mathrm{~cm})$ with a stainless steel cutting instrument equipped with blades that coupled to the table, even cuts were made in the horizontal and vertical directions.

For the experiment, randomly selected milk candy tablets with no apparent defects (cracked, malformed or broken) were placed in three different types of packaging: polystyrene packages $(0.50 \mathrm{~cm}$ thick and dimensions of $11.50 \mathrm{~cm} \times 19.00 \mathrm{~cm} \times 4.00 \mathrm{~cm})$ covered with a layer of stretchable PVC film ( $0.017 \mathrm{~mm}$ thick); PP pots with lid $(7.9 \mathrm{~cm}$ height $\times 11.9 \mathrm{~cm}$ diameter $)$; and PEBD packages with partial vacuum $(15 \mathrm{~cm} \times 15 \mathrm{~cm}$ with $0,010 \mathrm{~mm}$ thickness). Afterwards, the sweets were carefully transported to the Laboratory of Physical-chemical Analyses of Milk and Derivatives of the Goiano IF - Rio Verde Campus and stored in B.O.D (LimaTec LT 320 TFP-II) at $25^{\circ} \mathrm{C}$.

\subsection{Physico-chemical analyses}

\section{Instrumental colour analysis}

Colour determination was performed by reading three parameters defined by the CIE $L^{*} a^{*} b^{*}$ system. The parameters $\mathrm{L}^{\star}, \mathrm{a}^{\star}$ and $\mathrm{b}^{\star}$ were provided by a colorimeter (Color Flex, model CFEZ-4500L), in which $\mathrm{L}^{*}$ represents luminosity $\left(\mathrm{L}^{*}=0\right.$ black and $\mathrm{L}^{\star}=100$ white $)$ and $\mathrm{a}^{\star}$ and $\mathrm{b}^{\star}$ represent chromaticity $\left(+\mathrm{a}^{\star}=\right.$ red and $-a^{\star}=$ green,$+b^{\star}=$ yellow and $-b^{\star}=$ blue). From these coordinates, the hue and chroma angles were calculated using Equations 2 and 3. Fifteen replicates were performed with 6 replicates.

Angle Hue $=$ arco tangente $(\mathrm{a} / \mathrm{b})$

Chroma $=\left(a^{2} / b^{2}\right)^{1 / 2}$

\section{Analysis of the texture profile}

The texture profile analysis (TPA) was performed using a Brookfield Texturometer (CT3 model - Brookfield Engineering Laboratories, Middleborough, MA, USA) to obtain force-time curves. The analysis was conducted using a TA4/100 cylindrical probe, with a target of $30 \%$ sample strain; the trigger load was $5 \mathrm{~g}$, the pre-test velocity was $2.0 \mathrm{~mm} / \mathrm{s}$, the test velocity and return was $1.5 \mathrm{~mm} / \mathrm{if}$, and a load cell of $25 \mathrm{~kg}$ was used. The data were evaluated using TexturePro CT V1.5 Build 20 
(Brookfield Engineering Labs) to obtain the parameters of hardness, cohesiveness, adhesiveness, elasticity, fracturing and chewing according to Szczesniak (1995). All analyses were conducted at room temperature on samples ( $20 \mathrm{~mm}$ side cubes) in 15 replicates.

\section{Moisture, proteins, lipids and fixed mineral residue}

The moisture content was analysed according to the technique described by the Association of Official Analytical Chemists (2010); proteins according to the micro-Kjeldahl method (Association of Official Analytical Chemists, 2010); total lipids by means of the Bligh \& Dyer (1959) method; and fixed mineral residue by an AOAC method (Association of Official Analytical Chemists, 2010).

\subsection{Evaluation of yield}

The yield of the milk formula in tablets was calculated by means of Equation 4 proposed by Milagres et al. (2010):

$$
\operatorname{Yield}(\%)=\frac{\mathrm{SM} \times 100}{\mathrm{MDL}}
$$

where SM is the sum of the milk mass $(\mathrm{kg})$ and other ingredients used in the formulation and CDM is the milk mass $(\mathrm{kg})$ obtained.

\subsection{Statistical analyses}

The study was conducted in a completely randomised design (DIC) in a $3 \times 5$ factorial scheme, corresponding to three types of packages: Styrofoam trays with PVC, PP pots and bags of PEBD with partial vacuum. Five storage times were used: 0 (day after manufacture), 45, 90, 135 and 180 days. When the effect of the treatments on the studied parameters was verified through the $\mathrm{F}$ test of the analysis of variance (ANOVA), the means were compared by the Tukey test at $5 \%$ significance.

The physico-chemical and microbiological parameters of the samples were evaluated during storage. The results were evaluated using the STATISTICA ${ }^{\circ} 10.0$ program, and the graphics were plotted using the Microsoft Office Excel 2013 ${ }^{\circ}$ software system.

\section{Results and discussion}

The results of the analyses of the physical and chemical parameters of the milk candy in tablets are presented in Table 1.
All the packages and storage times tested were efficient for maintaining the physical-chemical parameters of the milk candy in tablets within the standards required by Ministerial Order No. 354 of September 4, 1997, of the Ministry of Agriculture, Livestock and Food Supply (Brasil, 1997), which establishes the identity and quality standard (PIQ) for milk candy.

The type of packaging and storage times studied significantly $(\mathrm{p}<0.05)$ influenced the physical-chemical parameters (moisture and protein contents) and instrumental colour, except for the lipid contents, which did not vary independently of the packaging used. The ash content did not change significantly according to the studied factors (type of packaging and storage time). In Figure 1, the results of the moisture, protein and lipid analyses for milk candy in elaborated tablets are presented.

The mean moisture content of the sweets stored in the polystyrene tray wrapped in PVC film was significantly $(\mathrm{p}<0.05)$ lower than that of sweets from the other treatments, with a loss of $64.14 \%$ in the free water content of the product over 180 days (Figure 1). This behaviour is due to the different permeabilities of the materials constituting the packages. According to Gorris \& Peppelenbos (1992), PVC is more permeable to water vapour than PEBD, contributing to the great loss of water observed in samples stored in the former type of packaging. PP, an option for semi-rigid and thermoformed packaging with mechanical resistance, low weight, reasonable oxygen protection and loss of moisture, was efficient in maintaining the initial moisture conditions until the end of the storage time (180 days). Milk packs must protect against moisture absorption and hinder the passage of oxygen, as well as prevent microbiological contamination (Martins \& Lopes, 1980). The behaviour of the moisture content of sweet products can be used as a parameter to define shelf life, type of packaging and adequate storage conditions (Ferreira et al., 2012).

The pulp wrapped in PP and PEBD presented a significant variation in moisture with similar behaviour up to 45 days of storage, and the PP pot was efficient in maintaining moisture up to six months. The vacuum-packed candies had a small increase in moisture during the first 45 days, with a small reduction and subsequent increase in moisture at 180 days of storage.

The ash content presented a tendency to increase with the length of storage time but did not differ statistically, and the values up to 180 days were in accordance with the legislation $\left(<2.0\right.$ g. $\left.100 \mathrm{~g}^{-1}\right)$. The average values of fixed mineral residues (ash) presented in this study were very similar and did not present significant variations ( $p>0.05$ ), which may be related

Table 1. Mean values of moisture (g. $\left.100 \mathrm{~g}^{-1}\right)$, ash $\left(\mathrm{g} .100 \mathrm{~g}^{-1}\right)$, protein $\left(\mathrm{g} .100 \mathrm{~g}^{-1}\right)$, and lipid $\left(\mathrm{g} .100 \mathrm{~g}^{-1}\right)$ content and coordinates of instrumental colour $\mathrm{L}^{*}$, chroma and angle hue $\left({ }^{\circ} \mathrm{H}\right)$ of the milk candy in tablets stored in different packages and kept at $25^{\circ} \mathrm{C}$ and $\mathrm{UR} 45-75 \%$.

\begin{tabular}{lccccccc}
\hline Treatments & Moisture & Ash & Proteins & Lipids & $\mathrm{L}^{*}$ & \multicolumn{1}{c}{ Chroma } & ${ }^{\circ} \mathrm{H}$ \\
\hline PVC & $5.84 \mathrm{c}$ & $1.76 \mathrm{a}$ & $7.15^{\mathrm{a}}$ & $8.00 \mathrm{a}$ & $37.16 \mathrm{a}$ & $18.77 \mathrm{a}$ & $62.38^{\mathrm{a}}$ \\
PP & $11.95 \mathrm{ab}$ & $1.64 \mathrm{a}$ & $6.79 \mathrm{~b}$ & $7.64 \mathrm{a}$ & $36.06 \mathrm{~b}$ & $16.29 \mathrm{~b}$ & $62.64^{\mathrm{a}}$ \\
PEBD & $12.17^{\mathrm{a}}$ & $1.82 \mathrm{a}$ & $6.99 \mathrm{ab}$ & $7.53 \mathrm{a}$ & $34.94 \mathrm{c}$ & $15.79 \mathrm{c}$ & $62.04^{\mathrm{a}}$ \\
Teste F & $3757.90^{*}$ & $0.87 \mathrm{~ns}$ & $15.36^{*}$ & $1.77 \mathrm{~ns}$ & $357.43^{*}$ & $1002.52^{*}$ & $1.69 \mathrm{~ns}$ \\
SMD (5\%) & 0.2385 & 0.4275 & 0.2926 & 0.9035 & 0.5915 & 0.4536 & 0.0152 \\
\hline
\end{tabular}

Means followed by the same, lower-case letter in the columns do not differ significantly from each other by the Tukey test at $5 \%$ probability. SMD: significant minimum difference. *indicates significant $(\mathrm{p}<0.05)$; ns indicates not significant $(\mathrm{p}>0.05) . \mathrm{PVC}=$ Styrofoam packs covered with a layer of $\mathrm{PVC}$ film; $\mathrm{PP}=$ polypropylene pots with lid; and $\mathrm{PEBD}=$ low-density polyethylene packages with partial vacuum. 
to the fact that the same batch of sweets was manufactured with the same environmental conditions, proportions and lots of ingredients. For Demiate et al. (2001), ash content is indicative of the presence of milk in the product because the former is a constant value in the raw material. However, high ash values may indicate excessive addition of salts such as sodium bicarbonate; conversely, low ash values may indicate a small amount of milk. Starch can also influence the ash content, with additions higher than the maximum permitted by legislation $(0.5 \mathrm{~g} / 100 \mathrm{~mL}$ milk $)$ to reduce production costs constituting fraud.

The evaluated samples had significantly different protein contents between treatments, except on day zero (Figure 1). The sample stored in packaging composed of PVC presented higher protein values than the others (in PP and PEBD packing), which did not differ from each other. This difference can be explained by the reduction in moisture, which results in the increase in the concentration of the other components of the candy. Feihrmann et al. (2006) observed higher values of protein $\left(10.2 \mathrm{~g} .100 \mathrm{~g}^{-1}\right)$ when determining the centesimal composition of pastes of pasty milk obtained in an evaporator. These authors assigned the high number of nitrogen compounds to the low heating temperature used, $50{ }^{\circ} \mathrm{C}$, which promoted lower denaturation of proteins. The present work was performed using the traditional process, with milk concentrated in an open pan with temperatures above $100{ }^{\circ} \mathrm{C}$, which influenced the protein content (Madrona et al., 2009). In addition, in the elaboration of milk candy in tablets, a long cooking time and, consequently, exposure to heat when compared to those for processing pasty milk are necessary due to the batting stage in which the crystal nets responsible for the texture of the product are formed. The protein content was observed to reduce over time, except when using vacuum packaging (PEBD).

The types of packages did not influence the lipid content ( $p>0.05)$, which decreased with the storage time (Figure 1). The milk sweets presented average lipid contents close to the upper limit established by the legislation ( 6.0 to $9.0 \mathrm{~g} .100 \mathrm{~g}^{-1}$ ), possibly because whole milk was used without prior fat standardisation. However, the values obtained in the present study are in agreement
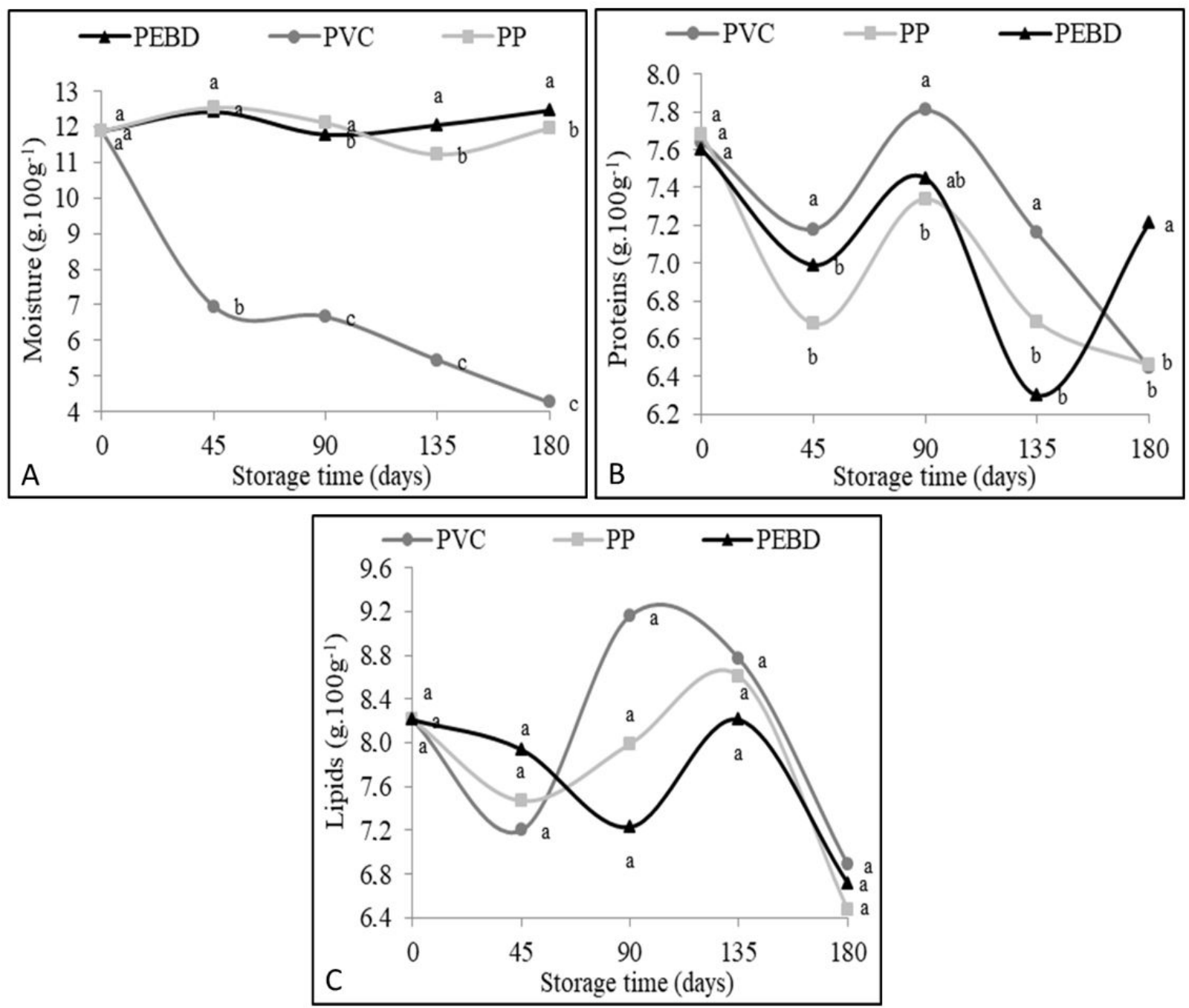

Figure 1. Moisture (g. $\left.100 \mathrm{~g} \mathrm{~g}^{-1}\right)$, protein (g. $100 \mathrm{~g} \mathrm{~g}^{-1}$ ), and lipid (g. $100 \mathrm{~g}^{-1}$ ) contents of milk candy in tablets packed in Styrofoam trays with polyvinyl chloride (PVC), polypropylene (PP) and low-density polyethylene (PEBD) and stored for 180 days at $25^{\circ} \mathrm{C}$ and UR $45-75 \%$. Means followed by the same lower-case letter in the same time period do not differ significantly from each other by the Tukey test at 5\% probability. Means followed by the same lower-case letter in the same time period do not differ significantly from each other by the Tukey test at $5 \%$ probability. 
with that recommended by Martins \& Lopes (1980), who stated that the fat content expected for sweet milk made from whole milk should be approximately $8.0 \mathrm{~g} .100 \mathrm{~g}^{-1}$.

Santos \& Marques (2010) evaluated five commercial samples of fresh milk sold informally in Currais Novos/RN and observed similar lipid contents as those in the present study, from $6.5 \%$ to $9.5 \%(\mathrm{~m} / \mathrm{m})$. Lower values were observed by Oliveira et al. (2010) when evaluating six commercial samples of milk candy whose lipid contents were equal to or less than $6 \%(\mathrm{~m} / \mathrm{m})$. Pieretti et al. (2013) observed lipid contents between 4.8 and 5.8 g. $100 \mathrm{~g}^{-1}$ for samples of milk candy made with whole milk and brown sugar. Francisquini et al. (2016) evaluated nine different brands of milk candy and found a high coefficient of variation in their fat content, varying from 1.25 to $5.50 \mathrm{~g} .100 \mathrm{~g}^{-1}(\mathrm{~m} / \mathrm{m})$. Demiate et al. (2001) suggested that the low lipid content observed in commercial samples may be related to the great industrial and technological interest in milk fat by dairy industries.

In Figure 2 , the results of the luminosity analysis, $\mathrm{a}^{*}$ and $\mathrm{b}^{*}$ values of milk candy in tablets are presented. The raw materials directly influence the colour of the food, which can be measured through the parameters of instrumental colour.

Luminosity $\left(\mathrm{L}^{*}\right)$ is directly proportional to the amount of light that is reflected by the sample, ranging from 0 (zero) for a black surface to 100 (one hundred) for a perfectly white surface (Guimarães et al. 2014). The luminosity values of the milk candy of the different packages presented similar behaviour up to 90 days of storage. In the final days of storage (135 and 180 days), there was a significant increase in $L^{*}$ for the candy packaged with PVC, which was lighter than that packaged with the other materials (PP and PEBD); these $\mathrm{L}^{*}$ values did not differ until
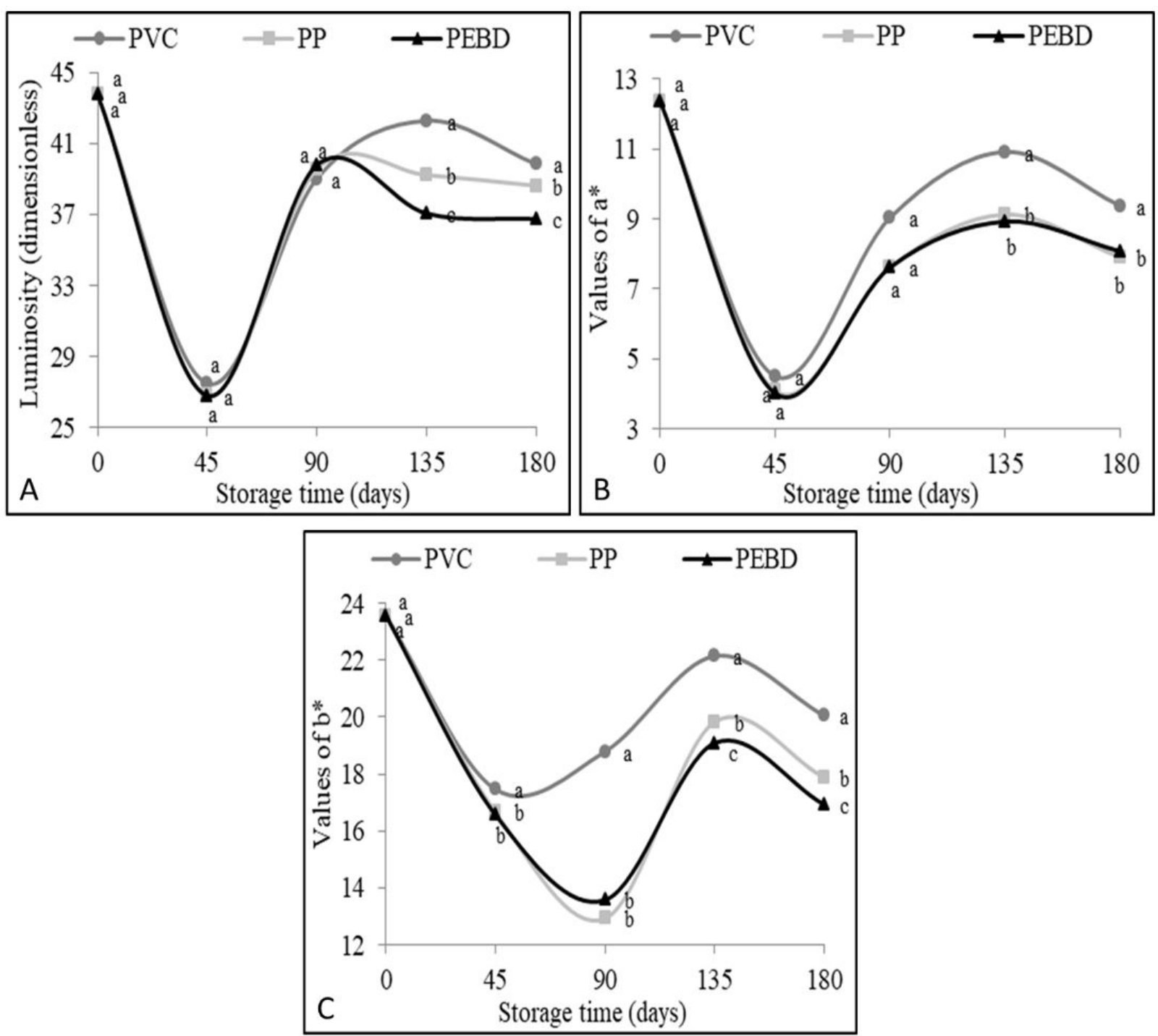

Figure 2. Luminosity (dimensionless) and values of $\mathrm{a}^{\star}$ and $\mathrm{b}^{\star}$ of milk candy in tablets packed in Styrofoam trays with polyvinyl chloride (PVC), polypropylene (PP) and low-density polyethylene (PEBD) in vacuum, stored for 180 days at $25^{\circ} \mathrm{C}$ and UR $45-75 \%$. Means followed by the same lower-case letter in the same time period do not differ significantly from each other by the Tukey test at $5 \%$ probability. Means followed by the same lower-case letter in the same time period do not differ significantly from each other by the Tukey test at 5\% probability. 
180 days (Figure 2 ). Turcatel et al. (2014) observed lower values of $L^{*}$ (7.98 to 11.16$)$ when evaluating six commercial samples of sweet pasty milk from different formulations. These authors concluded that changes in milk confectionery formulations made by the industry to reduce the cost of the final product may change the identity and characterisation of the product.

The final dark colouration of milk is influenced by different factors, such as milk acidity, dosage and application point of sodium bicarbonate, presence of reducing sugars, and vapour pressure, since they accelerate the Maillard reaction (Ferreira et al., 2012). When comparing the processes of manufacturing sweetened milk into tablets and paste, the colouration of the final product may be influenced by some parameters, such as a high soluble solids content and a batting stage (product specific in tablets) that requires long evaporation time/concentration.

The values expressed in the $\mathrm{a}^{*}$ axis can be negative or positive, so the intensity of these values represents the proximity of the colours of green $\left(-\mathrm{a}^{*}\right)$ to red $\left(+\mathrm{a}^{*}\right)$ (Borba et al., 2005). The values of $\mathrm{a}^{\star}$ for all packages are positive, indicating that the samples are in the red region (Figure 2).

The parameter $b^{*}$ varies from yellow $(+b)$, to positive values, to blue (-b), to negative values. The positive mean values observed for the $b^{*}$ coordinate (12.93 to 23.57 ) indicate that the milk candy in elaborated tablets presented wavelength reflection associated with the yellow colour (Figure 2), which, according to Silva et al. (2015), is due to caramelisation and the Maillard reaction.

The intensity of the yellow colour $\left(b^{*}\right)$ was significantly different for variable packaging types and times, indicating that their interaction was significant $(\mathrm{p}<0.05)$. During the shelf life, the PVC packaging was efficient in maintaining high values of wavelength reflection associated with the yellow colour compared to the other packages that showed a decrease in the intensity of the yellow colour, followed by PP and PEBD, respectively. Similar values of $b^{*}(12.32$ to 21.37$)$ were observed by Ferreira et al. (1989) and by Gaze et al. (2015) when evaluating commercial samples of commercial sweetmeat (17.89 and 27.70). No significant differences in the hue angle were observed between the treatments used, which varied during storage $(\mathrm{p}<0.05)$, with average values between 58 and $65^{\circ}$, showing a tendency of the milk candy in tablets to yellow. Higher values for chroma $\left(C^{*}\right)$ are observed when the values of coordinate $b^{*}$ are greater than those of coordinate $\mathrm{a}^{\star}$, as in the present study.

In Figure 3, the values of hardness (A), adhesiveness (B), cohesiveness (C), elasticity (D), fracturability (E) and chewing (F) during storage are presented. ANOVA showed that all textural parameters, except adhesiveness, were significantly influenced $(\mathrm{p}<0.05)$ by the type of packaging used and storage time.

The texture of the sweets packaged in PVC presented the highest values of hardness and fracture; consequently, there was a loss in the candy's ability to resume its initial condition (height) before compression (elasticity) and even less extensive deformation before rupture (cohesiveness). For Martins et al. (2011), the hardness and fracturability of sweets may increase during storage due to the high content of soluble solids and the reduction in water content, which increases the rigidity of the structure.
After 135 days of storage, the hardness of the sweets from the PVC treatment was greater than the maximum reading capacity of the equipment (texturometer) and, therefore, could not be analysed at 180 days. This characteristic may be related to the lower values of moisture presented by these samples because the PVC packaging presents moderate permeability to water vapour (Azeredo, 2012). These results suggest that a small force is required to compress milk in tablets in the mouth between the molar teeth when the candies are stored in PP and PEBD packages.

Silva et al. (2015) evaluated several formulations of sweetened milk in paste form with the addition of starch $\left(68.0 \pm 2{ }^{\circ} \mathrm{Brix}\right)$ and found that the mean values of hardness (maximum of $473.7 \mathrm{~g}$ ) were lower than those found in the present study. The difference in the texture kinetics of sweet pasty milk and milk in tablets may be related to the higher concentration of SS ( 86 to $88^{\circ} \mathrm{Brix}$ ) of the sweet in solid form, as the SS parameter directly influences the texture of this product (Chacón-Villalobos et al. 2013). In addition, when this candy is manufactured, the controlling or crystallisation stage that modifies its texture induces the formation of lactose and sucrose crystals (Perrone et al., 2011).

The adhesion profile did not differ between the treatments and over time, indicating that the force required to separate the compression probe from the sample of sweetened milk was statistically the same. The composition of milk candy can influence its texture. For Hough et al. (1992), the presence of solutions with long molecules and the presence of casein influence the viscosity and time of gelation, respectively. However, scientific information on the texture behaviour of milk candy is still scarce or non-existent in the case of sweets in tablet form.

Concurrently with the increase in hardness during storage, the elasticity of the PVC-packed confections was reduced to values close to zero (0.39); that is, there was a loss in the capacity of the sample to return to the initial form, resulting in the disintegration of the samples after application of the force. The other treatments, PP and PEBD, presented elasticity evolution with storage time with mean values of 10.57 and 11.02, respectively, at 180 days. Francisquini et al. (2016) found similar mean values of elasticity (9.94 to $25.11 \mathrm{~mJ}$ ) when evaluating 12 commercial brands of sweet pasty milk.

Chewiness is defined as the number of chews at a constant force required for the food to be swallowed. This parameter is calculated through a relation between hardness, cohesiveness and elasticity (Szczesniak, 1995). According to the presented results, the reduction in cohesiveness and elasticity possibly influenced the decrease in the chewability of the sweets stored in PVC. On the other hand, the brittle or fracturable characteristics exhibited by these samples during the first compression cycle of the texture analyser may have reduced the number of chews required for swallowing. The masticability of the PP- and PEBDpacked confections did not vary significantly $(\mathrm{p}<0.05)$ when comparing the first (0) and last (180) days.

Considering that the attributes of the packaging influence the consumer's purchase decisions and, as a consequence, their consumption, the improvement of the packaging must be continuous (Schuch et al., 2019). Therefore, it is suggested 

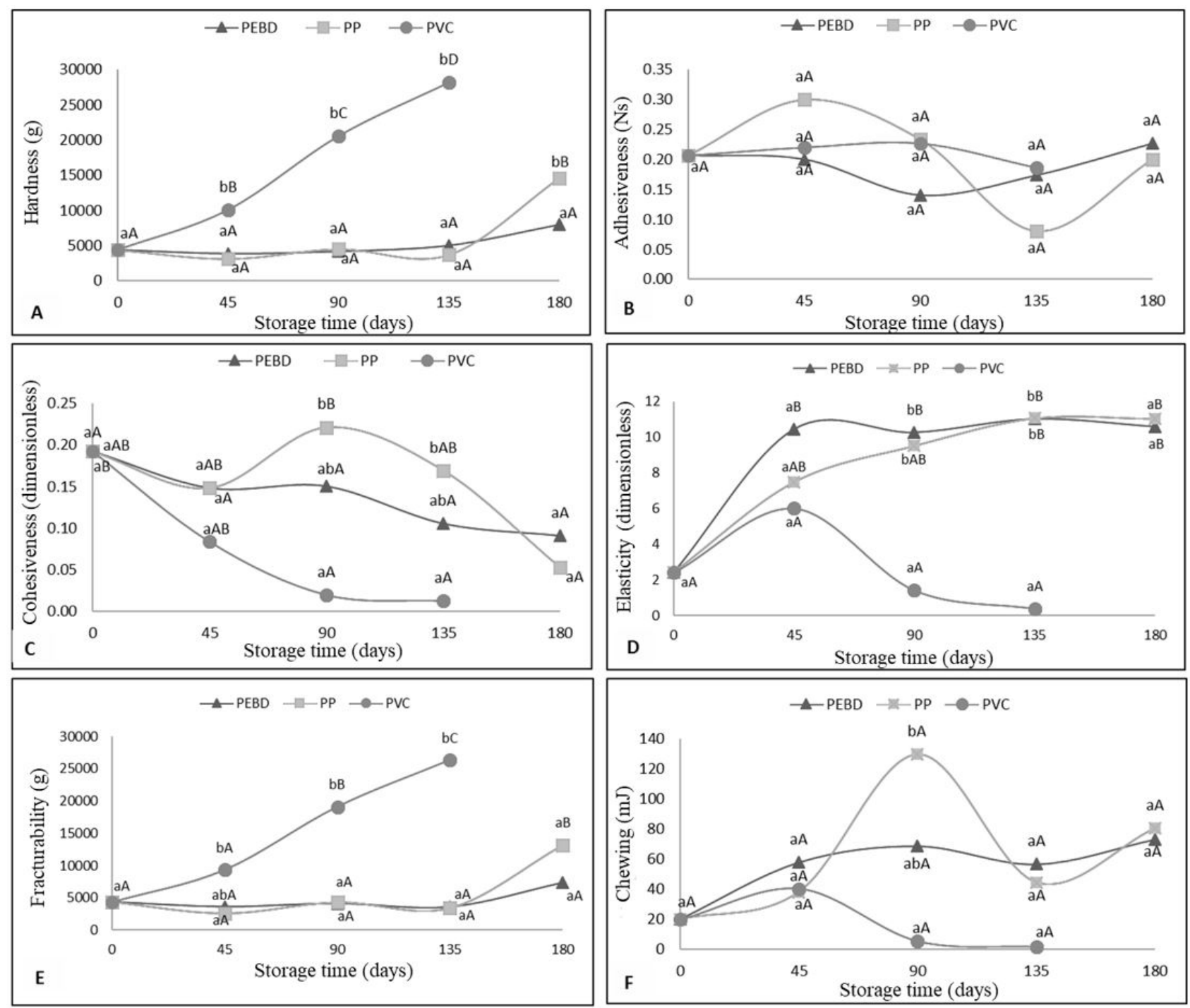

Figure 3. Variation in the mean values of hardness (A), adhesiveness (B), cohesiveness (C), elasticity (D), fracturability (E) and chewability (F) of milk candy in polystyrene trays packaged in polystyrene (PVC), polypropylene (PP) and low-density polyethylene (PEBD), stored at $25{ }^{\circ} \mathrm{C}$ and $45-75 \%$ RH during 180 days of storage.

to carry out a sensory analysis of the packaging in later works. Judacewski et al. (2019), state that using the word association technique makes it possible to assess the perceptions of consumers (and non-consumers), being a very interesting technique as it assesses the perception of both those who already consume the product and those who do not yet consume. Torres et al. (2017), used the check-all-that-apply (CATA) method, which consists of a list of attributes (words or phrases) from which evaluators can select those that they consider appropriate to describe a product, and concluded that the The questionnaire proved to be an effective tool to characterize different samples, and stated that the results of the present study can be useful for companies that manufacture dairy products.

\subsection{Income}

The batch of milk candy in tablets elaborated in the present work showed a yield of $32.42 \%$, and the total losses (3.45\%) were related to the separation of malformed or cracked samples or those from the edges. Similar values of $35.5 \%$ and $36 \%$ were found by Milagres et al. (2010) and Granda et al. (2005), respectively, when elaborating formulations of sweet pasty traditional milk. The milk candy in tablets presented a higher yield than that of the pasty milk because of the higher amount of sucrose added; however, there is a higher operating cost due to the longer process and concentration time. However, the manufacture of milk candy can compensate for the high cost as long as operational losses are controlled (Perrone et al., 2011).

\section{Conclusion}

The type and properties of the carton for the storage of milk candy in tablets directly influence the properties of the candy during its shelf life. According to the conditions studied, the packaging composed of Styrofoam trays wrapped in PVC is not recommended for the storage of milk candy in tablets due to the intense changes in the physical-chemical, texture and colour characteristics. In contrast, PP pots and vacuum-packed PEBD 
bags constitute efficient packaging materials for maintaining the initial properties of this type of candy. However, PEBD bags are more convenient for transporting and handling because there is no risk of detachment of the lid such as in the case of the PP pots.

\section{Acknowledgements}

The authors would like to thank the Goiano Federal Institute - Rio Verde Campus for all the necessary support for the development of this research.

\section{References}

Akarca, G. (2019). Lipolysis and aroma occurrence in Erzincan Tulum cheese, which is produced by adding probiotic bacteria and ripened in various packages. Food Science and Technology, 40(1), 102-116. http://dx.doi.org/10.1590/fst.33818.

Association of Official Analytical Chemists - AOAC. (2010). Official methods of analysis (18th ed.). Washington: AOAC.

Azeredo, H. M. C. (2012). Fundamentos de estabilidade de alimentos. Brasília: Embrapa.

Bligh, E. G., \& Dyer, W. J. (1959). A rapid method of total lipid extraction and purification. Canadian Journal of Biochemistry and Physiology, 37(8), 911-917. http://dx.doi.org/10.1139/o59-099. PMid:13671378.

Borba, A. M., Sarmento, S. B. S., \& Leonel, M. (2005). Efeito dos parâmetros de extrusão sobre as propriedades funcionais de extrusados da farinha de batata-doce. Food Science and Technology, 25(4), 835-843. http:// dx.doi.org/10.1590/S0101-20612005000400034.

Brasil, Ministério da Agricultura, Pecuária e Abastecimento. (1997, September 4). Aprova os Regulamentos Técnicos de Produção, Identidade e Qualidade do Leite tipo A, do Leite tipo B, do Leite tipo C, do Leite Pasteurizado e do Leite Cru Refrigerado e o Regulamento Técnico da Coleta de Leite Cru Refrigerado e seu Transporte a Granel (Portaria ${ }^{\circ} 354$, de 4 de setembro de 1997). Diário Oficial [da] República Federativa do Brasil.

Brasil, Ministério da Saúde, Agência Nacional de Vigilância Sanitária. (2002, October 26). Dispõe sobre o Regulamento Técnico de Procedimentos Operacionais Padronizados aplicados aos Estabelecimentos Produtores/Industrializadores de Alimentos e a Lista de Verificação das Boas Práticas de Fabricação em Estabelecimentos Produtores/Industrializadores de Alimentos (Resolução RDC n 275, de 21 de outubro de 2002). Diário Oficial [da] República Federativa do Brasil.

Brasil, Ministério da Agricultura Pecuária e Abastecimento. (2006, December 14). Oficializa os métodos analíticos oficiais físicoquímicos, para controle de leite e produtos lácteos, em conformidade com o anexo desta Instrução Normativa, determinando que sejam utilizados nos Laboratórios Nacionais Agropecuários (Instrução Normativa ${ }^{\circ}$ 68, de 12 de dezembro de 2006). Diário Oficial [da] República Federativa do Brasil.

Cardoso, A. E. M., Cardoso, L. M., Verruck, S., Canella, M. H. M., \& Prudencio, E. S. (2018). Emprego de prebiótico em doce de leite bubalino visando à redução da sacarose. Revista do Congresso Sul Brasileiro de Engenharia de Alimentos, 4(1), 1-11. http://dx.doi. org/10.5965/24473650412018001.

Chacón Villalobos, A., Pineda Castro, M. L., \& Méndez-Rojas, S. G. (2013). Efecto de la proporción de la leche bovina y caprina en las características del milk candy. Agronomía Mesoamericana, 24(1), 149-167. http://dx.doi.org/10.15517/am.v24i1.9792.
Demiate, I. M., Konkel, F. E., \& Pedroso, R. A. (2001). Avaliação da qualidade de amostras comerciais de doce de leite pastoso: composição química. Food Science and Technology, 21(1), 108-114. http://dx.doi. org/10.1590/S0101-20612001000100023.

Feihrmann, A. C., Cichoski, A. J., \& Jacques, A. R. (2006). Doce de leite elaborado em evaporador, com leite semi-desnatado concentrado. Revista Higiene Alimentar, 20(141), 29-32.

Fernandes, L. M., Guimarães, J. T., Silva, R., Rocha, R. S., Coutinho, N. M., Balthazar, C. F., Cavalcante, R. N., Piler, C. W., Pimentel, T. C., Cucinelli, R. P. No., Tavares, M. I. B., Esmerino, E. A., Freitas, M. Q., Silva, M. C., \& Cruz, A. G. (2020). Whey protein films added with galactooligosaccharide and xylooligosaccharide. Food Hydrocolloids, 104, 105755. http://dx.doi.org/10.1016/j.foodhyd.2020.105755.

Ferreira, L. O., Pereira, P. A. P., Maria, J., \& Pinto, S. M. (2012). Avaliação dascaracterísticas de qualidade de doces deleite comerciais. Revista do Instituto de Latícinios Cândido Tostes, 67(387), 5-11. http://dx.doi. org/10.5935/2238-6416.20120044.

Ferreira, V. L. P., Hough, G., \& Yotsuyanogi, K. C. (1989). Cor de doce de leite pastoso. Coletânea do Instituto de Tecnologia de Alimentos, 9(2), 134-145.

Francisquini, J. D., Oliveira, L. N., Pereira, J. P. F., Stephani, R., Perrone, I. T., \& Silva, P. H. F. (2016). Avaliação da intensidade da reação de Maillard, de atributos físico-químicos e análise de textura em doce de leite. Revista Ceres, 63(5), 589-592. http://dx.doi.org/10.1590/0034$737 \times 201663050001$.

Gaze, L. V., Oliveira, B. R., Ferrao, L. L., Granato, D., Cavalcanti, R. N., Conte, C. A. Jr., Cruz, A. G., \& Freitas, M. Q. (2015). Preference mapping of dulce de leche commercialized in Brazilian markets. Journal of Dairy Science, 98(3), 1443-1454. http://dx.doi.org/10.3168/ jds.2014-8470. PMid:25557891.

Gorris, L. G. M., \& Peppelenbos, H. W. (1992). Modified atmosphere and vacuum packaging to extend the shelf life of respiring food products. HortTechnology, 2(3), 303-309. http://dx.doi.org/10.21273/ HORTTECH.2.3.303.

Granda, T., Ramos, A. M., \& Teixeiras, L. J. Q. (2005). Formulação e avaliação de doce de leite em pasta sem adição de açúcar. In Anais do XXII Congresso Nacional de Laticínios. Juiz de Fora: EPAMIG.

Guimarães, F. I. T., Caliari, M., \& Soares, M. S. Jr. (2014). Instrumental analysis of texture, color and acceptance of instant dessert formulated with broken-rice grains. Food Science and Technology Research, 20(4), 785-792. http://dx.doi.org/10.3136/fstr.20.785.

Hentges, D., Silva, D. T., Dias, P. A., Conceicao, R. C. S., Zonta, M. N., \& Timm, C. D. (2010). Pathogenic microorganism survival in milk candy. Food Control, 21(9), 1291-1293. http://dx.doi.org/10.1016/j. foodcont.2010.02.014.

Hough, G., Bratchell, N., \& Macdougall, D. B. (1992). Sensory profiling of milk candy, a dairy based confectionary product. Journal of Sensory Studies, 7(1), 157-178. http://dx.doi.org/10.1111/j.1745459X.1992.tb00531.x.

Jacob, V. R., Roque, C. M., Silva, A. D. S. L., Neve, K. A. L., \& Otani, F. S. (2018). Aspectos de qualidade físico-química de doce de leite de búfalas da raça murrah, a partir de leite fresco e armazenado. Revista Agroecossistemas, 9(2), 288-298. http://dx.doi.org/10.18542/ ragros.v9i2.5122.

Judacewski, P., Los, P. R., Lima, L. S., Alberti, A., Zielinski, A. A. F., \& Nogueira, A. (2019). Perceptions of Brazilian consumers regarding white mould surface-ripened cheese using free word association. International Journal of Dairy Technology, 72(4), 585-590. http:// dx.doi.org/10.1111/1471-0307.12649. 
Madrona, G. S., Zotarelli, M. F., Bergamasco, R., \& Branco, I. G. (2009). Estudo do efeito da adição de soro de queijo na qualidade sensorial do doce de leite pastoso. Food Science and Tecnology, 29(4), 826-833. http://dx.doi.org/10.1590/S0101-20612009000400020.

Martins, G. A. S., Ferrua, F. Q., Mesquita, K. S., Borges, S. V., \& Carneiro, J. D. S. (2011). Estabilidade de doces em massa de banana Prata. Revista do Instituto Adolfo Lutz, 70(3), 332-340.

Martins, J. F. P., \& Lopes, C. N. (1980). Doce de leite: aspectos da tecnologia de fabricação. São Paulo: ITAL, 1980.

Milagres, M. P., Dias, G., Magalhaes, M. A., Silva, M. O., \& Ramos, A. M. (2010). Análise físico-química e sensorial de doce de leite produzido sem adição de sacarose. Revista Ceres, 57(4), 439-445. http://dx.doi.org/10.1590/S0034-737X2010000400001.

Oliveira, R. M. E., Oliveira, A. R. C., Ribeiro, L. P., Pereira, R., Pinto, S. M., \& Abreu, L. R. (2010). Caracterização química de doces de leite comercializados a granel em Lavras. Revista do Instituto de Latícinios Cândido Tostes, 65(377), 5-8.

Othman, S. H., Majid, N. A., Tawakkal, I. S. M. A., Basha, R. K., Nordin, N., \& Shapi'i, R. A. (2019). Tapioca starch films reinforced with microcrystalline cellulose for potential food packaging application. Food Science and Technology, 39(3), 605-612. http:// dx.doi.org/10.1590/fst.36017.

Pavlovic, S., Santos, R. C., Silva, M. E., \& Gloria, M. B. A. (1992). Effect of processing on the nutritive value of Doce de leite, atypical LatinAmerican confectionary product. Arquivos de Biologia e Tecnologia, 35(4), 691-698.

Perrone, I. T. (2007). Tecnologia para fabricação de doce de leite. Informe Agropecuário, 28(238), 67-74.

Perrone, I. T., Stephani, R., \& Neves, B. S. (2011). Doce de leite: aspectos tecnológicos. Juiz de Fora: Do Autor.

Pieretti, G. G., Seollin, V. J., Bento, R. S., Michika, J. M., Santos, R. D., \& Madrona, G. S. (2013). Doce de leite pastoso elaborado com açúcar mascavo:Avaliação sensorial, físico-química e microbiológica. Revista do Instituto de Latícinios Cândido Tostes, 68(390), 59-64. http://dx.doi.org/10.5935/2238-6416.20130009.

Pinto, R. V. (1979). Doce de leite: Fabricação tradicional. Revista do Instituto de Latícinios Cândido Tostes, 34(205), 37-38.
Santos, R. A., \& Marques, R. C. P. (2010). Análise microbiológica e físico-química de doce deleite vendido no comercio informal de Currais Novos/RN. Holos, 5, 131-136.

Schuch, A. F., Silva, A. C., da, Kalschne, D. L., Silva-Buzanello, R. A., \& da, (2019). Chicken nuggets packaging attributes impact on consumer purchase intention. Food Science and Technology, 39(Suppl. 1), 152-158. http://dx.doi.org/10.1590/fst.41317.

Silva, F. L., Ferreira, H. A. L., Souza, A. B., Almeida, D. F., Stephani, R., Pirozi, M. R., Carvalho, A. F., \& Perrone, Í. T. (2015). Production of milk candy: the effect of starch addition. Lebensmittel-Wissenschaft Food Science and Technology, 62(1), 417-423. http://dx.doi.org/10.1016/j. lwt.2014.10.062.

Souza, G., Oliveira, A. J., Shirose, I., Valle, J. L. E., \& Carvalho, C. R. L. (1990). Utilização de abóbora e moranga na produção de doce de leite pastoso com coco. Anais da Escola Superior Superior Luiz de Queiroz, 47(2), 609-623. http://dx.doi.org/10.1590/S007112761990000200019

Szczesniak, A. S. (1995). Texture profile analysis: methodology interpretation clarified. Journal of Food Science, 60(6), 7.

Timm, C. D., Conceição, R. C. S., Coelho, F. J. O., Roos, T. B., Tejada, T. S., \& Quevedo, P. S. (2007). Avaliação microbiológica de doce de leite pastoso. Revista do Instituto Adolfo Lutz, 66(3), 275-277.

Torres, F. R., Esmerino, E. A., Carr, B. T., Ferrão, L. L., Granato, D., Pimentel, T. C., Bolini, H. M. A., Freitas, M. Q., \& Cruz, A. G. (2017). Rapid consumer-based sensory characterization of requeijão cremoso, a spreadable processed cheese: Performance of new statistical approaches to evaluate check-all-that-apply data. Journal of Dairy Science, 100(8), 6100-6110. http://dx.doi.org/10.3168/ jds.2016-12516. PMid:28571992.

Turcatel, L. C., Pires, P. F. F., Diniz, P. R., Ferreira, S. M. R., Alves, M. A. O., \& Beux, M. R. (2014). Que doce de leite é esse? Uma discussão sobre o padrão de identidade e qualidade do doce de leite pastoso. Revista do Instituto Adolfo Lutz, 73(3), 302-308.

Vieira, L. C., \& Lourenço, J. B. Jr. (2004). Tecnologias de fabricação dos doces de leite pastoso e em tabletes. Belém: Embrapa Amazônia Oriental.

Zalazar, C. A., \& Perotti, M. C. (2011). Concentrated dairy products, milk candy. In J. W. Fuquay, P. Fox \& P. McSweeney (Eds), Encyclopedia of dairy science (3rd ed., pp. 874-880). Cornwall: Academic Press. 